кУЛЬТУРОЛОГІЯ

UDC 008: $379.8(38)$

\begin{abstract}
Цитування:
Гончарова О. М. Перегони на колісницях як розважальна форма івентів Давнього Риму у культурологічному вимірі. Вісник Національної академії керівних кадрів культури і мистецтв : наук. журнал. 2021. № 1. С. 3-12.
\end{abstract}

Goncharova O. (2021). Chariot racing as the entertainment form of ancient Rome events in the cultural studies dimension. National Academy of Culture and Arts Management Herald: Science journal, 1, 3-12. [in English].

\author{
Goncharova Olena, \\ Doctor of Science in Cultural Studies, professor, \\ professor of the Event Management and \\ Leisure Industry Department, \\ Kyiv National University of Culture and Arts \\ ORCID: https://orcid.org/0000-0002-8649-9361 \\ Researcher ID: F-6473-2015 \\ o.m_goncharova@yahoo.com
}

\title{
CHARIOT RACING AS THE ENTERTAINMENT FORM OF ANCIENT ROME EVENTS IN THE CULTURAL STUDIES DIMENSION
}

The purpose of the article is the introduction into the cultural discourse of analytically processed and summarized information on the genesis and evolution of chariot racing as the form of entertainment events in ancient Rome, their functional features, specific features of mass events of Antiquity in the context of entertainment culture of Rome. The methodological basis consisted of the methods of critical analysis of cultural, historical, and literary sources, specific and historical analysis, and interdisciplinary synthesis, induction, and deduction. The problematic and chronological, system and structural, comparative, descriptive methods and methods of social and phenomenological analysis were applied from specific and scientific methods. Scientific novelty. The article analyzes the genesis and evolution of chariot racing as a form of events in the context of entertainment culture in ancient Rome. Based on the ancient literary reflection, through the prism of works of culturologists, philosophers, historians, poets, writers of the ancient Rome Gaius Suetonius Tranquillus, annals of Publius Cornelius Tacitus, Cassius Dio, ethic works of Lucius Annaeus Seneca, letters of Gaius Pliny the Younger, poetry pages of Publius Ovidius Naso, epigrams of Marcus Valerius Martialis and others. The author revealed the essence and content of chariot racing as an entertainment form of events in ancient Rome, statistics, and specific features of entertainment events and instruments of ruling the Roman emperors. The author describes the moral aspects of chariot racing in the context of the entertainment culture of antiquity. Conclusions. The place of entertainment culture of Antiquity in the system of cultural knowledge and cultural tradition of their social universe is revealed. The transformations of chariot racing as a social and humanitarian experience of ancient society, the political instrument of government in Rome are explored. The role of entertainment of Antiquity for modern cultural practices is established.

Key words: chariot racing, gladiatorial shows, events, entertainment, mass spectacles, spectacular events, morality, Roman emperors, ancient Rome.

Гончарова Олена Миколаӥвна, доктор культурології, професор, професор кафедри івент менеджменту та індустрії дозвілля Київського національного університету культури і мистеитв

Перегони на колісницях як розважальна форма івентів Давнього Риму у культурологічному вимірі

Метою статті $\epsilon$ введення до культурологічного дискурсу аналітично обробленої та узагальненої інформації щодо генези та еволюції перегонів на колісницях як форми розважальних івентів у Давньому Римі, їх функціональних особливостей, особливостей масових подій Античності в контексті розважальної культури Риму. Методологічну основу склали методи критичного аналізу культурологічних, історичних та літературних джерел, конкретно-історичний аналіз та міждисциплінарний синтез, індукція та дедукція. Проблемні та хронологічні, системні та структурні, порівняльні, описові методи та метод соціального та феноменологічного аналізу застосовувались із конкретних та наукових методів. Наукова новизна. У статті проаналізовано генезу та еволюцію перегонів на колісницях як форми подій у контексті розважальної культури у Давньому Римі. Використовуючи античну літературну рефлексію, крізь призму творів культурологів, філософів, істориків, поетів, письменників Давнього Риму Гая Светонія Транквілла, анналів Публія Корнелія Тацита, історичних праць Кассія Діона, моральних творів Луція Аннея Сенеки, листів Гая Плінія Молодшого, елегій Публія Овідія Назона, епіграм Марка Валерія Марціала та ін. Розкрито сутність та зміст перегонів на колісницях як 
розважальної форми івентів у Давньому Римі, статисти++ку й особливості розважальних заходів та інструменти правління римських імператорів. Описано моральні аспекти перегонів на колісницях в контексті розважальної культури Античності. Висновки. Розкрито місце розважальної культури Античності в системі культурологічних знань та культурних традицій їх соціального універсуму. Досліджено трансформації перегонів на колісницях як соціального та гуманітарного досвіду античного суспільства, політичного інструменту управління в Римі. Встановлено роль розваг Античності для сучасних культурних практик.

Ключові слова: перегони на колісницях; гладіаторські шоу; івенти; розваги; масові видовища; видовищні івенти; розважальні івенти; мораль; римські імператори; Стародавній Рим.

Relevance of work. The scientific and popular science literature is devoted to entertaining ancient culture and its individual forms. The authors of some of these cultural studies, philosophical, historical, literary, and pedagogical studies have already become classics and indisputable authorities in this field: $J$. Burckhardt, F. Cowell, O. Losiev, Th. Mommsen, G. Hyofling, I. Schiffman, R.C. Beacham, L. Gorgerat, A. McCullough, J. Nelis-Clement, D. McLean, T. Wiedemann, G. Woolf, and others. However, while focusing on the ancient leisure as, above all, free time, often insufficient attention is paid to the moment that performances of athletes, poets, rhapsodists, actors and gladiators, chariot racing were public, so they were the forms of existing entertainment events - prototypes of modern cultural and leisure, and recently - due to television - entertainment shows in the leisure industry.

Games and chariot racing form a kind of mirror in which a society can, if it so desires, inspect itself. In its imperialist culture, the image that Rome wants to give of itself through its mass spectacles is one that knows no limits: everything must be put to use in order to illustrate and emphasize Roman power and grandeur. As a result, its spectacles become an essential defining element of Roman culture, helping to display the extent of Rome's control over the known world. For all their violence and cruelty the games underpin the pax romana and a sense of world domination, order, and control. Part of what it is to be Roman involves attending the games, going to watch in the arena elements of the dominated world, enslaved enemies and convicted criminals, beasts hunted from all over the empire [25, 255].

The reference point for the axiological approach in the social and cultural sphere is the values of spectacular forms of Antiquity events, the study of which is productive and certainly significant for modern entertainment culture. Paintings, sculptures, museum exhibitions, novels, movies, television series, comics, plays, and historical reconstructions at Roman festivals are devoted to the theme of the chariot racing as the entertainment events of ancient Rome that indicates the long-standing interest of the public, and not just the scientific one.

The analysis of recent research and publications shows that, despite the number of publications devoted to the leisure, entertainment, and entertainment of Ancient Rome of this period, there are almost no studies representing chariot racing.

Chariot races were analyzed as a religious form of celebration (F. Cowell), in terms of the tools of imperial power (J. Burkhard), the role of the individual in history (I. Schiffman), the divinity of the individual, and the power of the emperor (G. Woolf), as the category of Roman aesthetics (A. Losev), human activity and cultural traditions of their social universe (B. Chumachenko), as the household history of imperial Rome (L. Friedlander), the policy of "bread and spectacles" of aediles, emperors (G. Hyofling), forms, organization and financial costs of mass spectacles and entertainment (Th. Mommsen, T. Wiedemann), from the standpoint of feminism (A. McCullough), through the prism of the environmental implications of Roman spectacles (J. Nelis-Clement), spectacle entertainments in early imperial Rome (R. C. Beacham).

On the other hand, less attention was usually paid to games, entertainment, performances, and events of the ancient world in the studies of G. Avanesova, O. Genkina, O. Kliusko, I. Petrova, B. Chumachenko devoted to the leisure culture.

Therefore, the author of this article aims to define the genesis and evolution of chariot racing as the form of events in ancient Rome, to investigate its functions, to establish how the Antiquity horse racing arose in the context of entertainment culture of Rome.

The methodological basis of the article consists of the methods of critical analysis of cultural, historical, and literary sources, specific and historical analysis, and interdisciplinary synthesis, induction, and deduction. The problematic and chronological, system and structural methods, as well as the method of social and phenomenological analysis, were applied from specific and scientific methods. New approaches to the study of cultural and historical 
process increase the opportunities in investigation of entertainment events as a social and cultural phenomenon, identification of the place of horse racing in entertainment culture of Antiquity in the system of cultural knowledge, in the cultural tradition of their social universe [5, 33-34].

The genesis and evolution of chariot racing as the entertainment form of events of Antiquity, functional features of cultural and leisure practices, specific features of the spectacular culture of Antiquity can be investigated by analyzing the historical works of Gaius Suetonius Tranquillus, annals of Publius Cornelius Tacitus, Cassius Dio, ethic works of Lucius Annaeus Seneca, letters of Gaius Pliny the Younger, poetry pages of Publius Ovidius Naso, epigrams of Marcus Valerius Martialis and others.

Presenting of the main content of the article. The axiological principles of leisure of the ancient society were based on political and personal liberty of the individual, education of model paradigmatic citizen, on the priority of polytheistic religion and state ideology, active development of visual, literary, and dramatic creativity [19, 11-12]. In general, there are no differentiation in the culture in the ancient world to which we are used - folk and scientific culture, mass and elite, formal and informal, local (peripheral, provincial) and capital (cultural metropolitan), no bohemianism, underground, youth culture, etc. [19, 24].

Free time, quantity, and quality of leisure become a measure of a person's social wealth in Antiquity. Power, politics, war as arete, leisure, sports, and physical culture are valued, but the physical labor is neglected. Amphitheaters, theaters, stadiums, circuses, hippodromes, courts are the most visited places by the Romans. The Romans built what they needed for play, leisure, entertainment, and events as a necessary condition of the Roman way of life. The ancient Romans loved agons and spectacles, entertainment, ludi, chariot racing and naumachia, but were more likely as passive spectators than participants, despising gladiators as criminals and actors as comedians [19, 57]. According to V. Panchenko, under the influence of Hellenism, the Romans learned to value themselves, but at the same time asserted selfishness, hedonism, humiliation [11, 172].

Among the forms of mass spectacles of ancient Rome, the Spanish researcher R. Beacham identifies ... triumph ceremonies, funerals, gladiatorial shows, shows with wild animals, processions in the circus, which was influenced significantly by the Roman, Etruscan and African traditions. The ideas of celebrations were influenced by political, social, religious characteristics, and state control [21, 280].

The origin of Roman games, festivals and spectacle are inseparable from the history of local beliefs, cults, and religious ceremonies. The ancient Italians did not know the anthropomorphism, and it was only under the influence of the Etruscans (and later the Greeks) that the Romans began to represent their gods and goddesses in human form.

The winners of games and competitions in the Roman Empire were honored, about which Pliny the Younger wrote in a letter to Emperor Trajan "The winning athletes in the Triumphal Games, Sir, think that they ought to receive the prizes which you have awarded on the day they are crowned for victory. They argue that the actual date of their triumphal entry into their native towns is irrelevant; the date which matters is that of the victory which entitled them to the triumph" [13, X, 118].

The entertainment nature of the ancient Roman culture of events was so pronounced that the games, for example, later became an important component of domestic politics. The German historian Th. Mommsen writes that a certain amount of 200000 aces (14500 thalers) was allocated from the state treasury for the games and that amount was not increased until the Punic Wars. These funds were managed by aediles, which had to cover all sorts of accidental expenditures themselves $[9,365]$.

The more customized leisure becomes characteristic of representatives of the upper classes, elite, self-employed people who were able to use slaves. According to G. Woolf, the social link between education, social mobility, and acculturation suggest that this representation played a role in the creation of the imperial elite by joining local elite groups to the empire [26, 320].

The spectacles in Rome were a form of cult celebrations, a form of honoring the gods, a kind of mystery, mass entertainment, and had a competitive nature. The spectacular events of ancient Rome were magnificent, even under the criteria of our time. In the cultural and leisure sphere in ancient Rome, the customized forms of leisure were increasingly opposed to mass, domestic to socially organized, intellectual activities were shifted towards physical, spiritual, and developing forms of leisure were partly replaced by spectacles encompassing thousands of people at the same time.

As the philosopher, O. Losev notes, during the time of the Republic there were seven annual games, which lasted sixty-six days in August. And 
almost all of them prospered in the IV century AD! The most wonderful, the most amazing spectacles were gladiatorial fights and circus games. ... Fireworks, rope dancers, magicians, equilibrists, etc. joined here for brilliance and variety. It seems that only Rome started the first night performances, using illumination, lamps, and lighting vessels. Praetor Lucius Sejanus, for example, during Floralius forced 5,000 slaves to light the way home for the spectators. Analyzing the moral and aesthetic side of ancient spectacles, the O. Losev writes, perhaps you will ask: what is it? As you delve into Roman spectacles and try to understand the essence of the Roman amphitheater, you will ask: what is it? What is this bloodthirsty, hysterical, bestial aesthetics? What is this sensuality at the sight of senseless carnage, at the sight of blood, at the sight of a whole mountain of corpses? There is only one answer to these questions: this is Rome, this is magnificent, antique, pagan Rome! [7].

According to L. Friedlander, the passion for the stage, arena, and circus could be compared with an epidemic disease, which did not spare the upper classes either [17, 257].

The French scientist J. Nelis-Clement in her monograph "Roman Spectacles: exploring their environmental implications" pays attention, that the biggest spectacles were the games and other events usually presented in a circus or in an amphitheater. In the city of Rome, the capacities of the Circus Maximus and the Flavian Colosseum represented respectively c. $15 \%$ and $5 \%$ of the population of the city (estimated at one million in the I century AD). The shows displayed in a circus, the ludi circenses, consisted mainly of chariot-races, the maxima spectacula as Ovid calls them, for which the monument was specially designed. The oldest and biggest of this kind of entertainment building in Rome was the Circus Maximus. Livy and Dionysius of Halicarnassus associate its origins with Tarquinius Priscus, who held games in the space between the Aventine and Palatine hills, and this place was destined to become in time one of 'most admirable structures in Rome', with a capacity of 150,000 spectators, a figure in line with modern estimations [25, 233234].

Emperor Claudius should be noted among the game organizers, as he often showed large and numerous spectacles, entertainment, and not only ordinary and in ordinary places: he invented new and renewed old ones. As the Roman historian Gaius Suetonius Tranquillus writes in the biography of the Roman emperors "The Twelve Caesars. Divine Claudius", he often arranged circus games even in the Vatican, sometimes showing venatio after every five races. "In Circus Maximus... Here, in addition to chariot racing, he also represented the Trojan Games and African baiting with participation of a squad of Praetorian horsemen led by the stands and the prefect himself, as well as brought out the Thessalian horsemen with wild bulls whom they chased around the circus, picked up the exhausted ones on the back and threw them to the ground" [14, V.21]. During the reign of the Emperor Claudius there were 159 public festivals per year, 93 of which were devoted to games at the expense of government expenditures, including celebrations in honor of national heroes and victories in battles $[26,320]$.

The Roman historian Publius Cornelius Tacitus in his "Annals" among the active hobbies of another Emperor Nero (stepson of Claudius O.G.) notes such an activity as "riding horses in the tiltyard" [16, XIII.3]. Even Tacitus himself was a priest-quintecimvir, organizer during secular games hosted by Emperor Claudius. "During the games that took place at the circus in the presence of Claudius, teenagers from noble families, among them Britannicus, son of the emperor, and Lucius Domitius (Nero - O.G.) ... gave a Trojan performance on horseback" [16, XI.10].

The chariot racing was particularly popular in Rome and, despite being very dangerous, they did not have the deliberate cruelty of fighting as in fighting of man with wild beasts. In the city of Rome and its environs, entertainment buildings were numerous, ubiquitous, and imposing. In this survey, before turning our attention to the provincial world, a rapid enumeration will be enough to give an idea of the amount of resources required for the construction of the entertainment buildings in Rome and of their maintenance throughout the centuries. Leaving aside some temporary structures and wooden buildings, which have not survived, we will focus mainly on a selection of the major building projects (mostly from the 1st century $\mathrm{BC}$ on), among which we can count:

- 6 circuses: the Circus Maximus; the Circus Flaminius, which is more an open multifunctional space than a monumental circus; the circus built by Caligula and transformed by Nero, known as Circus Vaticanus; the Circus Varianus, built by Caracalla and used by Elagabalus for his own chariot-racing performances; the Circus of Maxentius, along the via Appia (with a capacity of 10,000); the Arval Circus in the grove of the Fratres Arvales, along the via Campana, c. $7.5 \mathrm{~km}$ outside Rome; 
-4 theatres: the already mentioned theatre of Scaurus (58 BC), the theatres of Pompey (55 BC), of Balbus (13 BC) and of Marcellus (dedicated 13 $\mathrm{BC}$, or perhaps $11 \mathrm{BC}$, but already in use in 17 BC for the Ludi Saeculares), with capacities estimated of $11,000,7,700$ and 13,000 or 14,000 ;

- 5 amphitheatres: three in the Campus Martius, one built in stone by Statilius Taurus (29 $\mathrm{BC})$, burned down in $64 \mathrm{AD}$ in Nero's fire, and two in wood, the first, whose construction was begun by Caligula and already abandoned by Claudius, and then Nero's wooden amphitheatre, completed within a single year (57 AD), which was also damaged or destroyed in the fire of 64 AD. Two other buildings were the Amphitheatrum Castrense built by Elagabalus in the area between Porta Maggiore and the Laterano, near the Circus Varianus and the horti Variani, and the famous Colosseum, whose construction on the site occupied by Nero's domus aurea was planned by Vespasian and financed by the booty brought to Rome in $70 \mathrm{AD}$ at the end of the campaign in Judaea. This enormous building with a capacity of 50,000 was dedicated ten years later by Titus with lavish spectacles, also financed by the gold and the money taken from Judaea, as the spectators on their way to the arena and passing through the Arch of Titus and looking at the iconographical representations were reminded [25, 235-236].

At Circus Maximus (Circo Massimo) most of the viewers were sitting on wooden seats behind the front stone rows that were intended for the Vestal, senators and horsemen. Four teams, owned by contractors, competed for favor of the crowd - red, green, white and blue, named so for the color of clothing of the chariot drivers standing on fragile two-wheeled chariots behind two or four horses, wrapping the reins around their bodies. They needed to free themselves quickly by cutting the reins if the chariot turned over. The emotions run high on the side of one of these team colors and could split families and destroy friendships. Remembering the victories of one of the most famous chariot driver Diocles (about 150 AD), G. Hyofling in "Ancient Rome. Life, religion, culture" describes his tombstone. It contains the story of 3000 victories in racing on two-horse chariots, and of 1462 victories in chariots harnessed of more than two horses [18].

However, not all residents of Rome favored such races. Pliny the Younger in his letter to Calvisius mentions the circus games, noting that he does not favor such empty vulgar spectacles and prefers literary work. The Roman horsemen familiar with literary works of Cornelius Tacitus and Pliny the Younger himself (except that the audience confounded these authors, asking which of them was "Italian" and which was "provincial") were among the visitors to circus games [13, IX.23].

The author is amazed by the mass interest in chariot racing and the fact that "thousands of men should be eager, like a pack of children, to see horses running time after time, and the charioteers bending over their cars. There might be some reason for their enthusiasm if it was the speed of the horses or the skill of the drivers that was the attraction, but it is the racing-colors which they favor, and the racing-colors that fire their love. If, in the middle of the course and during the race itself, the colors were to be changed, their enthusiasm and partisanship would change with them, and they would suddenly desert the drivers and the horses, whom they recognize afar and whose names they shout aloud. Such is the influence and authority vested in one cheap tunic, I don't say with the common crowd, - for that is even cheaper than the tunic, - but with certain men of position; and when I consider that they can sit for so long without growing tired, looking on at such a fruitless, cheerless, and tedious sport" [13, IX.6].

The constant mass spectacles, including bloody ones, required considerable organizational work with the public and special premises.

The Colosseum was inaugurated by the Emperor Titus with the most generous games. It was announced that they would last a hundred days. The fights to the death were expected between more than 10000 people condemned to death and 5000 wild animals. On the second day, horse racing was to be held, and on the third - a naval battle between 3000 people on the artificial lake, which a water-filled arena turned into [6]. As Thomas Wiedemann notes in the book "Emperors and Gladiators", the Colosseum symbolized the emperor's own legitimacy, demonstrating that he returned the Roman people their right to decide and choose life or death. It was appropriate that the inauguration of the new birth of Roman freedom should be celebrated not only by the traditional slaughter of animals. Each time, during the battles, gladiators displayed the spectacle of death and rebirth in the presence of the Roman people. The audience had to accept mortality, reflecting on the unprecedented strength and continuity of the universal rules of Rome [28, 180].

The fact that the several hundreds of theatres and odeons, amphitheatres, stadia, and circuses we know today represent only a relatively small part of the buildings constructed, transformed or restored, means we must tread carefully in our 
analyses. Several aspects come into play, such as types, sizes, locations, choice of materials, durability and maintenance, when we try to gauge the impact of all these buildings on the urban environment. Just to give a rough idea of numbers and distribution: according to recent surveys, over 230 amphitheatres are known today in the entire Roman world, among which c. 210 are located in Italy, Gaul and Germany, North Africa, Britain and in the Danubian provinces; in Italy, Roman theatres are counted by hundreds, whereas in the Western provinces, as regards the number of theatres and amphitheatres, Gaul is at the top with its 115 theatres and 50 amphitheatres [25, 242].

In the document "Res gestae divi Augusti" (The Deeds of the Divine Augustus) (in Latin and Greek versions it is known from inscription in Ankara on Monumentum Ancyranum - O.G.), the Emperor Octavian Augustus details the statistics of mass entertainment and their costs [20, 184]. However, the Emperor Octavian Augustus was not the first to arrange public death battles.

As Jacob Burckhardt considers, the Emperor Constantine the Great organized lavish celebrations and majestic circus games for inauguration of new city construction and giving it the name of Constantinople. Each year, a gilded statue of the emperor with Tyche, genius guard of the city, was carried through the circus in a torchlight procession. In the case of Constantine, the excessive pride and pompous performances were aimed at a deliberate political purpose. After $322 \mathrm{AD}$, wine, bread and oil was distributed on a permanent basis $[2,86]$.

When analyzing the classification of gladiators, fighting couples, differences of their helmets and armor, role of gladiatorial shows in the mass interaction of the emperor with people of Roman Principate, the Swiss historian and museum expert Laurent Gorgerat in the study "Gladiator. Highly specialized fighter in the service of Roman virtues" identifies such types of gladiators as tracker, murmillo, provocator, hoplomachus, retiarius, secutor, arbelas $[23,86-$ 87]. Their goal has always been the will to fight at the highest technical level and thus to increase the attractiveness for the audience. The horse fighters, such as the andabata, were among them; their body was covered in Parthian chain mail and their faces were covered with deaf helmet with no slots for eyes. They were armed with long spears that they pointed at each other at full speed. The essedarii fought in British chariots operated by the driver standing near [18].

Cassius Dio in his "Roman History" mentions the shrine of Augustus. Boys of the noblest families, both of whose parents must be living, together with maidens similarly circumstanced, sang the hymn, the senators with their wives and also the people were banqueted, and there were spectacles of all sorts. For not only all kinds of musical entertainments were given, but also horse-races took place on two days, twenty heats the first day and forty the second, because the latter was the emperor's birthday, being the last day of August (Gaius Caesar, also called Caligula. - O. G.). And he exhibited the same number of events on many other occasions, as often as it suited him; previously to this, it should be explained, not more than ten events had been usual. He also caused four hundred bears to be slain on the present occasion together with an equal number of wild beasts from Libya. The boys of noble birth performed the equestrian game of "Troy," and six horses drew the triumphal car on which he rode, something that had never been done before [22, 59.7.1]. Roman historian considers that for the expenses connected with the

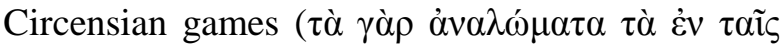

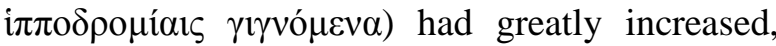
since there were usually 24 races [22, 60.27.2].

It is unknown when the female gladiator first appeared, as American researcher Anna McCullough writes in the article "Female Gladiators in Imperial Rome: Literary Context and Historical Fact". Their appearance probably coincided with the increasing popularity of games in general in the late Republican and Augustus era. B. Levick believes that women were first banned from entering the arena in $22 \mathrm{BC}$ by Augustus in the senatus consultum, which also banned the children and grandchildren of senators and horsemen from performing on stage and in the arena. Although Cassius Dio does not write specifically that women have been banned, he does mention both noble men and noble women who are banned from entering the arena in 23 and 22 BC. This ban of S.C. senate from being on stage and in the arena, if it did involve women, was repeated in $19 \mathrm{AD}$ and was also applied to the daughters, granddaughters and greatgranddaughters of senators and horsemen. In 11 $\mathrm{AD}$, the senate ban was applied to the free-born women under the age of twenty who could not enter the arena [24, 198].

Roman women as well as men found gladiatorial contests, and gladiators, attractive. Thomas Wiedemann draws attention to some much-quoted epigraphic evidence suggests that this attraction might be sexual: at Pompeii, the retiarius Crescens was known as 'the netter of girls by night' and 'the girls' darling'. Thracians were a favourite symbol of manliness because much of their body was left visible to the 
audience. Author considers that obviously constituted a potential danger to the Roman male's control over his womenfolk. Augustus restricted women, other than the six Vestal Virgins, to watching gladiators from the rearmost rows of seats [28, 26]. However, Wiedemann's publication "Emperors and Gladiators" reflected his understanding of the essence of the Roman universe.

The Roman poet Marcus Valerius Martialis dedicated his epigram to Hermes, one of the most popular gladiators at the time:

Hermes, his plumed helmet

drooping, to be feared,

Hermes, glory of all kinds of

war,

Hermes, alone is all and three

in one [8, V.31].

However, in other people such violent fun and gladiatorial shows caused aversion and disgust, and in moral sense - condemnation. The Roman philosopher, poet and statesman of the I century AD, Lucius Annaeus Seneca, describes in his "Moral Letters to Lucilius" the favorite spectacle of many Romans: “... there is no helmet or shield to deflect the weapon. What is the need of defensive armor, or of skill? All these mean delaying death. In the morning they throw men to the lions and the bears; at noon, they throw them to the spectators. The spectators demand that the slayer shall face the man who is to slay him in his turn; and they always reserve the latest conqueror for another butchering. The outcome of every fight is death, and the means are fire and sword. This sort of thing goes on while the arena is empty" [15, VII, 3-4].

The Roman poet Ovidius condemned the bloody fun of his contemporaries and in his "Grieving elegies" fervently called on the princeps (except for the other - Octavian Augustus), either jokingly or seriously, to ban the games, spectacle, chariot racing and circus.

Even if I'd confessed it, the

games also sow

seeds of iniquity: order the

theatres closed!

Many have often found an

excuse for sin

when the hard earth's covered

with Mars's sand!

Close the Circus! The Circus's

freedom isn't safe:

here a girl sits close to an

unknown man.

Why's any portico open, since certain girls stroll there, to meet a lover in

the place? [10, II, 1].

The leveling power of the imperial regime destroyed or falsified all patriarchal and ethnic and polis connections between people. The warmth of friendly feelings and real informal solidarity and friendship of ordinary people, family and community relations remained only in the collegiums [12].

For many of the religious cultures of the empire it is preferable to imagine a continuum stretching from men to the greatest creator deities. Emperors were the lowest of the gods, and the greatest of men. They were the greatest of priests and the least of all those beings that were paid cult [27, 248]. Ruler cult in the Roman world represented, a re-emergence in the region of a very widespread tendency to focus worship on powerful individuals.

Scientific novelty. The article analyzes the genesis and evolution of chariot racing as the form of events in the context of entertainment culture in the ancient Rome. Based on the ancient literary reflection, through the prism of works of culturologists, philosophers, historians, poets, writers of the ancient Rome the author had revealed the essence and content of chariot racing as entertainment form of events in the ancient Rome, statistics and specific features of entertainment events and instruments of ruling the Roman emperors. The author had described the moral aspects of chariot racing in the context of entertainment culture of antiquity.

Conclusions. Thus, chariot racing as the entertainment form of events of the ancient Rome became an effective instrument of political domination. This sphere is truly a Roman art sphere, as it shows with utmost clarity and expressiveness, according to A.F. Losiev, how legal absolutism is synthesized in Rome with sensual diversity and internal sensual exaltation [7]. The Imperial Rome is a country of complete and true absolutism, kingdom of some state mysticism, before which a separate individual simply does not exist, he is only a screw in this universal machine.

The chariot racing as the entertainment form of events in the era of the ancient Rome were not just a form of everyday or social behavior, realization of religious and public festivals and mass spectacles, but largely reflected certain life positions, served as an important criterion for assessing the social role of person in the community, specified political power, reflected social and cultural transformations in society. 
The forms of events of free citizens of the ancient Rome can be divided into those that took place at home and those that took place in public place; rural and urban; active and passive; individual, group and mass; training, entertaining, educational; constructive and destructive; selforganized and socially organized. The cultural consciousness then decides according to its own faith and tastes - mimesis or fantasy, nature or creativity, rules or freedom, rationality or emotions, objective or subjective.

In antiquity, there are two types of leisure activities: types and forms of leisure associated with religious worship, including mythology, traditional rites and rituals, mass actions, where, according to the classification of values of the ancient leisure, the leading values are cult and agony $[3,6]$; types and forms of leisure associated with household activities, daily activities, individual characteristics of participants of leisure activities of the antiquity, where the values of orientation to communication and compensatory activity appear as primary ones.

The strengthening of supreme power in the state leads to the emergence of triumphs and religious and political festivals (first, festivals of the emperors - the phenomenon of the Roman Empire), chariot racing. The Roman entertainments were a public demonstration of power, including the military. Quite often chariot racing are carried out at the expense of the state, which significantly distinguishes them from the spectacles of sacred content, or are organized due to allowances of the officials who dream of relevant state positions. A new leisure paradigm is being created that depends on many factors social conditions, cultural resources, dominant ideologies and beliefs.

In ancient Rome, labor and events differentiate becoming independent spheres of human life. They are closely intertwined with popular culture, folklore and folk festivals in the representatives of the broad circles. The leisure of wealthy and noble people takes new forms enriching with new content. The professions are born, the representatives of which are engaged in the organization of entertainment of nobility in free time, as well as engaged in artistic crafts, art, and philosophy. The specialists organizing public festivals and mass entertainment appear. The state plays an important role in organizing chariot racing, honoring festivals, as it is interested in formation of appropriate stereotypes of thinking and behavior of citizens, and forming public opinion.

The study of events of the Antiquity opens up new perspectives for the study of entertainment culture in historical retrospect, for the enrichment of the content and forms of the modern leisure industry, optimization of modern methods of event management, improvement of quality of education of cultural scientists, as theoretical foundations of School of Cultural Studies of Kyiv National University of Culture and Arts.

\section{Jimepamypa}

1. Аванесова Г. А. Культурно-досуговая деятельность: теория и практика организации. М.: Аспект Пресс, 2006. 236 с.

2. Буркхард Якоб. Век Константина Великого. М.: Центр полиграф, 2003. 367 с.

3. Генкина Е. В. Ценности античного досуга как социально-культурная система: дис. ... канд. пед. наук: 13.00.05. СПб, 1998. 217 с.

4. Гончарова О. М. Дозвілля античності в контексті видовищної культури : гладіаторські ігри. Вісник Національної академії керівних кадрів культури і мистецтв. К.: Мілленіум, 2015. Вип. 2. С. 20-26.

5. Клюско Е. М. Досуг в контексте современных взглядов на историографию. Социально-культурная деятельность: опыт исторического исследования; сб. стат. под. науч. ред. Е. М. Клюско, Н. Н. Ярошенко. М.: МГУКИ, 2007. $143 \mathrm{c}$.

6. Коуэл Ф. Древний Рим. Быт, религия, культура. М.: Центрполиграф, 2006. URL: http://historylib.org/historybooks/Drevniy-Rim--Byt-religiya--kultura/ (accessed 12 грудня 2019).

7. Лосев А. Ф. Эллинистически-римская эстетика І-ІІ веков. Под ред. А. А. Тахо-Годи, В. П. Троицкого. М.: Мысль, 2002. Т. 5. Кн. 2. URL: http:// psylib.org.ua/books/lose009/txt03.htm (accessed 2 Листопада 2020).

8. Марциал М. В. Эпиграммы. Пер. Ф. А. Петровского. СПб.: АО «Комплект», 1994. URL: http://ancientrome.ru/antlitr/t.htm? $\mathrm{a}=1312800455$ (accessed 12 Грудня 2019).

9. Моммзен Т. Искусство и наука. История Рима. Отв. ред. А. Б. Егоров, ред. Н. А. Никитина. СПб: «Наука», «Ювента», 1997. с. 365.

10. Овідій Публій Назон. Любовні елегії. Мистецтво кохання. Скорботні елегії. Пер. А. Содомори. К.: Основи, 1999. 300 с.

11. Панченко В. І. Культура Стародавнього Риму. Навч. посіб. під кер. Л. Т. Левчук. К.: Центр учб. літ., 2010. 400 с.

12. Петрова I. В. Форми дозвілля в античності: культурологічний потенціал. URL: http:// www.culturalstudies.in.ua/knigi_8_45.php (accessed 12 березня 2020).

13. Письма Плиния Младшего: Книги $\mathrm{I}-\mathrm{X}$. Изд. Сергеенко М. Е., Доватур А. И. 2-е издание. 1982. $407 \mathrm{c}$.

14. Светоний Г. Т. Жизнь двенадцати цезарей. Пер. с лат., предисл. и послесл. М. Гаспарова. М.: Худ. литература, 1990. 255 с. URL: http:// 


\section{Вісник Національної академії керівних кадрів культури і мистецтв № 1’2021}

ancientrome.ru/antlitr/t.htm?a=1354644432 (accessed 15 Січня 2020).

15. Сенека Луций Анней. Нравственные письма к Луцилию. Пер., прим. С. А. Ошерова, отв. ред. М. Л. Гаспаров. М.: Наука, 1977. (Серия «Литературные памятники»). URL: http://yakov.works/acts/01/2/seneca_001.htm (accessed 8 березня 2019).

16. Тацит Корнелий. Анналы. Анналы. Малые произведения. История. Пер. с лат. М.: ООО «Издво АСТ»; «Ладомир», 2001. 992 с. (Классическая мысль).

17. Фридлендер Л. Картины из бытовой истории Рима в эпоху от Августа до конца династии Антонинов. Общая история европейской культуры. Пер. Ф. Зелинского, С. Меликовой. Том IV. Ч. I. СПб. Изд. «Брокгауз-Ефрон», 1914. 628 с. C. 503-527. URL: http://ancientrome.ru/publik/article.htm?a=1262896623

18. Хефлинг Х. Римляне, рабы, гладиаторы: Спартак у ворот Рима. М.: Центр полиграф, 2010. URL: http://historylib.org/historybooks/KHelmutKHefling_Rimlyane--raby--gladiatory-Spartak-uvorot-Rima/2 (accessed 29 жовтня 2020).

19. Чумаченко Б. М. Вступ до культурології античності. К.: Вид. дім «КМ Академія», 2003. $100 \mathrm{c}$.

20. Шифман И. Ш. Деяния Божественного Августа. Цезарь Август. Л.: Наука, 1990. 200 с. (Серия «Из истории мировой культуры»).

21. Beacham R. C. Spectacle Entertainments in early imperial Rome. Revista de Estudios Latinos (RELat), 2001. V. 1. p. 280.

22. Cassius Dio. Roman History. Vol. I of the Loeb Classical Library edition, 1914. URL: https://penelope.uchicago.edu/Thayer/E/Roman/Texts/ Cassius_Dio/59*.html

23. Gorgerat L. Der Gladiator. Ein hochspezialisierter Kämpfer im Dienste römischer Tugenden. Gladiator - Die wahre Geschichte. Eine Ausstellung des Antikenmuseum Basel und Sammlung Ludwig. Basel, Steudler Press AG. September 2019. pp. 86-87.

24. McCullough A. Female Gladiators in Imperial Rome: Literary Context and Historical Fact. Classical World. Johns Hopkins University Press. Vol. 101. Number 2. Winter 2008. p. 198.

25. Nelis-Clement Jocelyne. Roman Spectacles: exploring their environmental implications. O. D. Cordovana - G. F. Chiai (eds.), Pollution and the Environment in Ancient Life and Thought, Geographica Historica, 36. Stuttgart, 2017. pp. 217281.

26. Woolf, Gregory Duncan. Inventing empire in ancient Rome. Empires Perspectives from archaeology and history. editors S. E. Alcock; K. D. Mor; T. N. D’Altroy, K. D. Morrison, C. M. Sinopoli. Cambridge University Press, 2001. p. 320.

27. Woolf, Gregory Duncan. Divinity and power in Ancient Rome. Religion and Power Divine Kingship in the Ancient world and beyond. Ed. by N. Brisch. Chicago: The University of Chicago;
McNaughton\&Gunn, Saline, Michigan, 2008. pp. 235252.

28. Wiedemann, Thomas E. J. Emperors and Gladiators. London; New York: Routledge. 1995. 198 p.

\section{References}

1. Avanesova G. A. (2002). Cultural and leisure activities: theory and practice of organization. M.: Aspect Press [in Russian].

2. Burckhardt Jacob (2003). The Age of Constantine the Great. M.: Polygraph Center, [in Russian].

3. Genkina E.V. (1998). Values of the ancient leisure as social and cultural system: $\mathrm{PhD}$ in Pedagogy Thesis: 13.00.05. St. Petersburg [in Russian].

4. Goncharova O. M. (2015). Dozvillja antychnosti $\mathrm{v}$ konteksti vydovyshhnoji kuljtury : ghladiatorsjki ighry. Visnyk Nacionaljnoji akademiji kerivnykh kadriv kuljtury i mystectv. K.: Millenium, 2, 20-26 [in Ukrainian].

5. Kliusko E. M. (2007). Leisure in the context of modern views on historiography. Social and cultural activities: experience of historical research; collection of articles. Sc. ed. E.M. Kliusko, N.N. Yaroshenko. M.: MGUKI [in Russian].

6. Cowell F. (2006). Ancient Rome. Life, religion, culture. M.: Centrpoligraf. Retrieved from: http://historylib.org/historybooks/Drevniy-Rim--Byt-religiya--kultura/ (accessed on December 12, 2019) [in Russian].

7. Losiev A. F. (2002). Hellenistic-Roman aesthetics of the I-II centuries. Editors A.A. TakhoGodi, V.P. Troitsky. M.: Mysl, Vol. 5, Book 2. Retrieved from: http://psylib.org.ua/books/lose009/txt03.htm (accessed on November 2, 2020) [in Russian].

8. Martialis M.V. (1994). Epigrams. Translation by F.A. Petrovskyi. St. Petersburg: JSC "Komplekt". Retrieved from: http://ancientrome.ru/antlitr/t.htm?a=1312800455 (accessed on December 12, 2019) [in Russian].

9. Mommsen Th. (1997). Art and Science. History of Rome. Editor-in-chief A.B. Yegorov, editor N.A. Nikitin. St. Petersburg: "Nauka", "Yuventa" [in Russian].

10. Ovidius Publius Naso (1999). Love elegies. Art of love. Grieving elegies. Translated by A. Sodomora. K.: Osnovy [in Ukrainian].

11. Panchenko V. I. (2010).Kuljtura Starodavnjogho Rymu. Navch. posib. pid ker. L. T. Levchuk. K.: Centr uchb. lit. [in Ukrainian].

12. Petrova I.V. Forms of leisure in antiquity: cultural potential. Retrieved from: http://www.culturalstudies.in.ua/knigi_8_45.php (accessed on March 12, 2020) [in Ukrainian].

13. Pliny the Younger: Letters: Books I-X]. (1982). Sergeenko M.E., Dovatur A.I. (editors). [in Russian].

14. Suetonius G.T. (1990). The Twelve Caesars. Translation from Latin, foreword and afterword of M. Gasparov. M.: Khudozhestvennaya literature. 
Retrieved

from:

http://ancientrome.ru/antlitr/t.htm?a=1354644432

(accessed on January 15, 2020) [in Russian].

15. Seneca Lucius Annaeus (1977). Moral letters to LuciliusTranslation, notes by S.A. Osherov, ed.-inchief M.L. Gasparov. M.: Nauka, VII, 3-4. Literary Monuments series. Retrieved from: http://yakov.works/acts/01/2/seneca_001.htm (accessed on March 8, 2019) [in Russian].

16. Tacitus Publius Cornelius (2001). Annals. Small works. History. Translation from Latin. M.: Publishing House AST LLC; Ladomir, 992 p. [in Russian].

17. Fridlender L. Kartiny iz bytovoy istorii Rima $\mathrm{v}$ epokhu ot Avgusta do kontsa dinastii Antoninov. Obshchaya istoriya evropeyskoy kul'tury. Per. F. Zelinskogo, S. Melikovoy. Tom IV. Ch. I. SPb. Izd. «Brokgauz-Efron», 1914. 628 s. S. 503-527. Rezhym dostupu:

http://ancientrome.ru/publik/article.htm?a=1262896623

18. Hyofling G. (2010). Romans. Slaves. Gladiators. Spartacus at the gates of Rome. M.: Center polygraph. Retrieved from: http://historylib.org/historybooks/KHelmut-

KHefling_Rimlyane--raby--gladiatory-Spartak-uvorot-Rima/2 [in Russian].

19. Chumachenko B.M. (2003). Introduction to the cultural studies of antiquity. K.: KM Akademiia Publishing House [in Ukrainian].

20. Shifman I.S. (1990). The Deeds of the Divine Augustus. Caesar Augustus. L.: Nauka, [in Russian].

21. Beacham R.C. (2001). Revista de Estudios Latinos (RELat), Vol. 1 [in English].

22. Cassius Dio. Roman History. (1914). Vol. I of the Loeb Classical Library edition. https://penelope.uchicago.edu/Thayer/E/Roman/Texts/ Cassius_Dio/59*.html[in English].
23. Gorgerat L. (September 2019). Der Gladiator. Ein hochspezialisierter Kämpfer im Dienste römischer Tugenden. Gladiator - Die wahre Geschichte. Eine Ausstellung des Antikenmuseum Basel und Sammlung Ludwig. Basel, Steudler Press AG, pp. 86-87. [in English].

24. McCullough A. (Winter 2008). Female Gladiators in Imperial Rome: Literary Context and Historical Fact. Classical World. Johns Hopkins University Press. Vol. 101, No. 2, p. 198. [in English].

25. Nelis-Clement Jocelyne. (2017). Roman Spectacles: exploring their environmental implications. O. D. Cordovana - G. F. Chiai (eds.), Pollution and the Environment in Ancient Life and Thought, Geographica Historica, 36. Stuttgart. pp. 217-281. [in English]

26. Woolf, Gregory Duncan (2001). Inventing empire in ancient Rome. Empires Perspectives from archaeology and history. Editors S.E. Alcock; K.D. Mor; T.N. D’Altroy, K.D. Morrison, C.M. Sinopoli. Cambridge University Press [in English].

27. Woolf, Gregory Duncan (2008). Divinity and power in Ancient Rome. Religion and Power Divine Kingship in the Ancient world and beyond. Ed. by N. Brisch. Chicago: The University of Chicago; McNaughton\&Gunn, Saline, Michigan. pp. 235-252. [in English].

28. Wiedemann, Thomas E.J. (1995). Emperors and Gladiators. London; New York: Routledge [in English].

Стаття надійшла до редакиії 14.08.2020 Отримано після доопрачювання 14.09.2020 Прийнято до друку 21.09.2020 